\title{
A Tribute to Joseph Schieser Nelson, 1937-2011
}

\section{Alison M. Murray ${ }^{1}$, Michael G. Sullivan ${ }^{2}$, and John Acorn ${ }^{3}$}

${ }^{1}$ Department of Biological Sciences, University of Alberta, Edmonton, Alberta T6G 2E9 Canada; email: ammurray@ualberta .ca

${ }^{2}$ Fish and Wildlife Division, Alberta Sustainable Resource Development, Edmonton, Alberta T6H 4P2 Canada; email: michael .g.sullivan@gov.ab.ca

${ }^{3}$ Department of Renewable Resources, University of Alberta, Edmonton, Alberta T6G 2H1 Canada; email: jacorn@ualberta.ca

Murray, Alison M., Michael G. Sullivan, and John Acorn. 2011. A tribute to Joseph Schieser Nelson, 1937-2011. Canadian Field-Naturalist 125(4): 373-380.

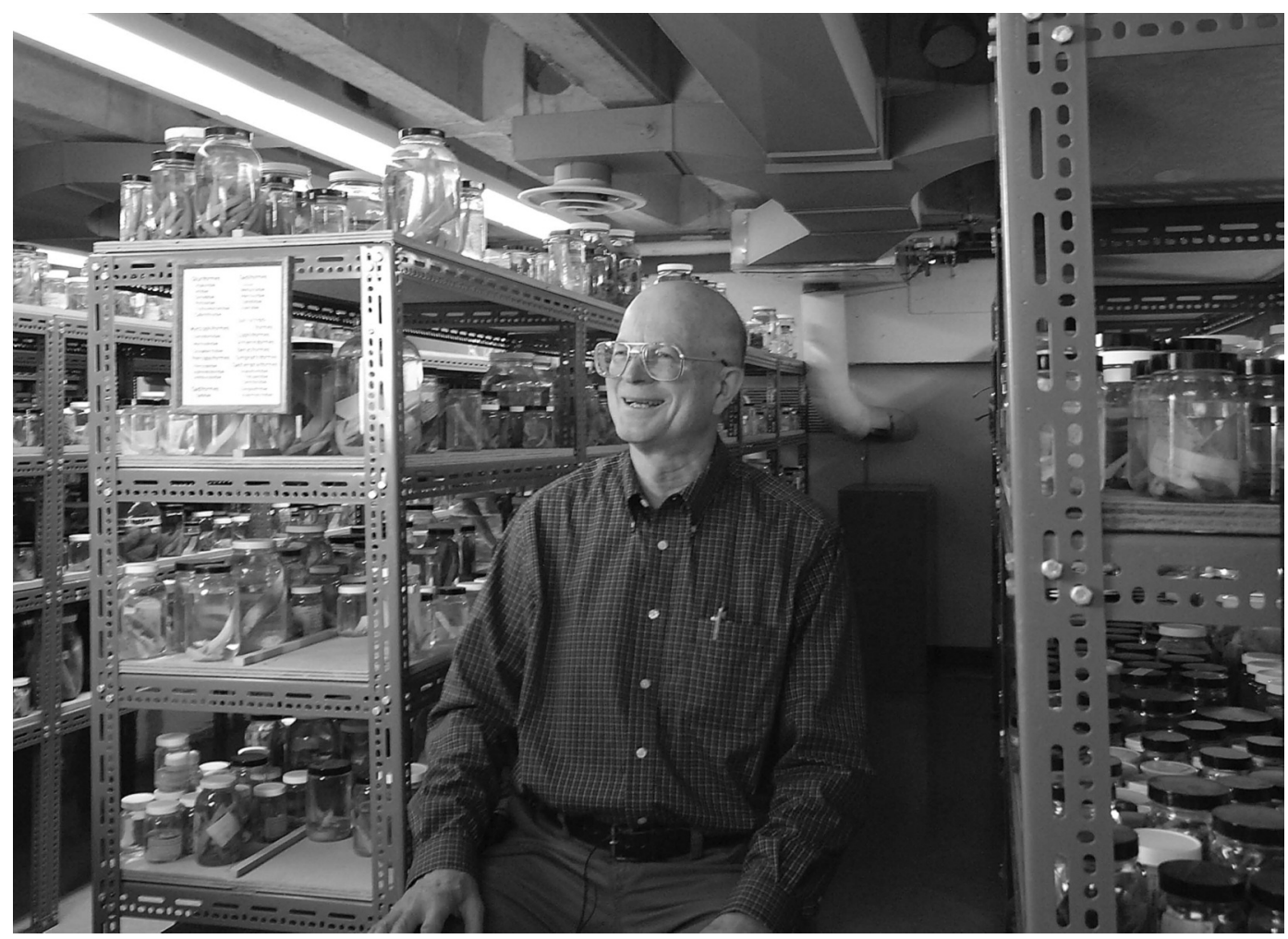

FIGURE 1. Joseph S. Nelson in the fish collection of the University of Alberta Museum of Zoology, circa 2008. Photo: Emma Gilbertson.

“Tiger Joe," who died 13 August 2011, was one heck of a fine fellow. Joseph Schieser Nelson (Figure 1) was born 12 April 1937 in San Francisco, California, his parents' third child, 10 and 13 years younger than his brothers. Eight months later, Joe's father, a mining engineer, moved the family to Allenby, near Copper Mountain in the Thompson Okanagan region of British Columbia - a move from the 12th largest city in the United States, with more than 600000 people at the time, to a small town with only 68 homes. Thus, Joe grew up surrounded by the outdoors, in a place rich with fish-filled lakes. Later, in his high school years in Vancouver, Joe also kept himself surrounded by fishes as an aquarist.

Despite a passionate interest in astronomy, Joe turned to ichthyology at the University of British Columbia, where he was influenced by many well-known, or soonto-be-well-known, names such as Cas Lindsey and Don McPhail. He completed an honour's thesis there, in 1960, on Kokanee Salmon (Oncorhynchus nerka). 
From Vancouver, Joe ventured to the other side of the Rockies, and he spent the next two years at the University of Alberta, in Edmonton, pursuing an M.Sc. degree under the supervision of J. Ralph Nursall. Joe returned to Vancouver in 1962 and began his Ph.D. with Cas Lindsey. For his dissertation, he examined hybridization between two Catostomus sucker species. Joe built an ungainly hatchery near Prince George to rear the offspring of his artificially hybridized fish. His supervisor thought privately that the gangling contraption would never work, but he was wrong. In fact, it worked beautifully!

During this time, Joe also met his future wife, Claudine, whom he married on 31 August 1963; they were married for nearly 48 years. Joe is survived by Claudine and their four children-Brenda (Mark Brown), Janice (David Kelly), Mark, and Karen (Rob Baron)—and four grandchildren-Anna Nicholls, Kaitlind Kelly, and twins Zaria and Zephran Kelly. Joe was a devoted and loving husband to Claudine and a superb father to his children. They always speak glowingly of him, especially of their experiences in the field with their father when they were kids. In his later years, meeting Joe in the hallway inevitably led to a recent story about his grandchildren.

After his doctoral studies, Joe briefly returned to the United States as a Research Associate at Indiana University, where he became Assistant Director of the Indiana University Biological Stations. During this sojourn in the south, Joe began his work on stickleback fishes, investigating Ninespine Sticklebacks (Pungitius pungitius) in the Missouri River drainage. His interest in the Gasterosteidae continued throughout his life, and his last submitted paper was on variation in Brook Stickleback (Culaea inconstans) populations in Astotin Lake, Alberta. In all, Joe published over 120 scholarly articles (listed below).

Joe returned to the University of Alberta in 1968 as an Assistant Professor, and he remained there for the duration of his career, progressing through Associate Professor and then attaining the top rank of Professor, and eventually taking on a number of administrative positions, including Associate Dean of Student Services for the Faculty of Science. He supervised 18 master's and 9 doctoral projects, and his students went on to positions in institutions throughout the world, including Iran (Dr. Yasdan Kievany, Isfahan University of Technology), Brazil (Dr. Ierecê Maria de Lucena Rosa, Universidade Federal da Paraíba), Thailand (Dr. Jaranthada Karnasuta, Permanent Secretary, Ministry of Agriculture and Cooperatives), as well as closer to home (e.g., Dr. Mrinal Das, MacEwan University, Alberta; Dr. James Reist, Fisheries and Oceans Canada Freshwater Institute, Manitoba). Joe was also responsible for the teaching and research collections of fishes as the Curator of Ichthyology for the University of Alberta Museum of Zoology (UAMZ). These collections were greatly increased during his tenure as Cura- tor, and Joe also enhanced the diversity of fish represented, providing many additional taxa for ichthyology students to learn.

To most people, Joe was best known as the author of Fishes of the World and as the co-author (with Martin Paetz) of The Fishes of Alberta. Both of these books are classics in their fields, and both have won high praise from biologists. Joe participated fully in the ichthyological community with memberships in many organizations, including the American Elasmobranch Society, American Fisheries Society, American Society of Ichthyologists and Herpetologists (and Chairman of the associated Names of Fishes Committee), Canadian Society of Zoologists, Canadian Society of Environmental Biologists, Canadian Society for Ecology and Evolution, Federation of Alberta Naturalists, Ottawa Field-Naturalists' Club, European Ichthyological Union, Ichthyological Society of Japan, Société Française d'Ichtyologie, Society of Systematic Biologists, and Society of Vertebrate Paleontology.

He also was on the editorial board of Fish and Fisheries and was part of the International Commission on Zoological Nomenclature for many years. He also served on the Committee on the Status of Endangered Wildlife in Canada (COSEWIC) from 1981 until 2007, first as a member of the Fish and Marine Mammals Subcommittee and then, after the subcommittees were reorganized, on the Freshwater Fishes Subcommittee.

In recognition of his contributions to the study of fishes, Joe was the recipient of many awards, some of which were the Fry Medal (Canadian Society of Zoologists, 2010), Robert H. Gibbs, Jr. Memorial Award and the Robert K. Johnson Award (2002 and 2010, respectively, American Society of Ichthyologists and Herpetologists), and the Distinguished Service Award (as chair of the Names of Fishes Committee) and the William E. Ricker Resource Conservation Award (2000 and 2011, respectively, American Fisheries Society).

During his career, Joe named 20 species and one genus of fishes (list below). Four species of fishes were also named for Joe: Barilius nelsoni Barman, 1988 (Cyprinidae) from River Gumti, northeastern India; Bembrops nelsoni Thompson \& Suttkus, 2002 (Perciformes) from the Philippine Islands and western Indian Ocean; Granulacanthus joenelsoni Hanke, Wilson, \& Lindoe, 2001 (an extinct Silurian acanthodian) from the Northwest Territories, Canada; and Myopsaron nelsoni Shibukawa, 2010 (Perciformes) from Japan.

Of course, Joe was much more than an academic; he was also an extremely likeable and inspiring person. Early on in his career, he acquired the nickname "Tiger Joe," the origins of which are now obscure. Some say it was his tenacity that made him Tiger Joe; others say the name was a bit of irony, since his demeanour was generally not at all tiger-like. We advocate for the following "Tiger Joe" nickname creation myth. During the extensive field work necessary to collect data for the original Fishes of Alberta book, Joe's two field 


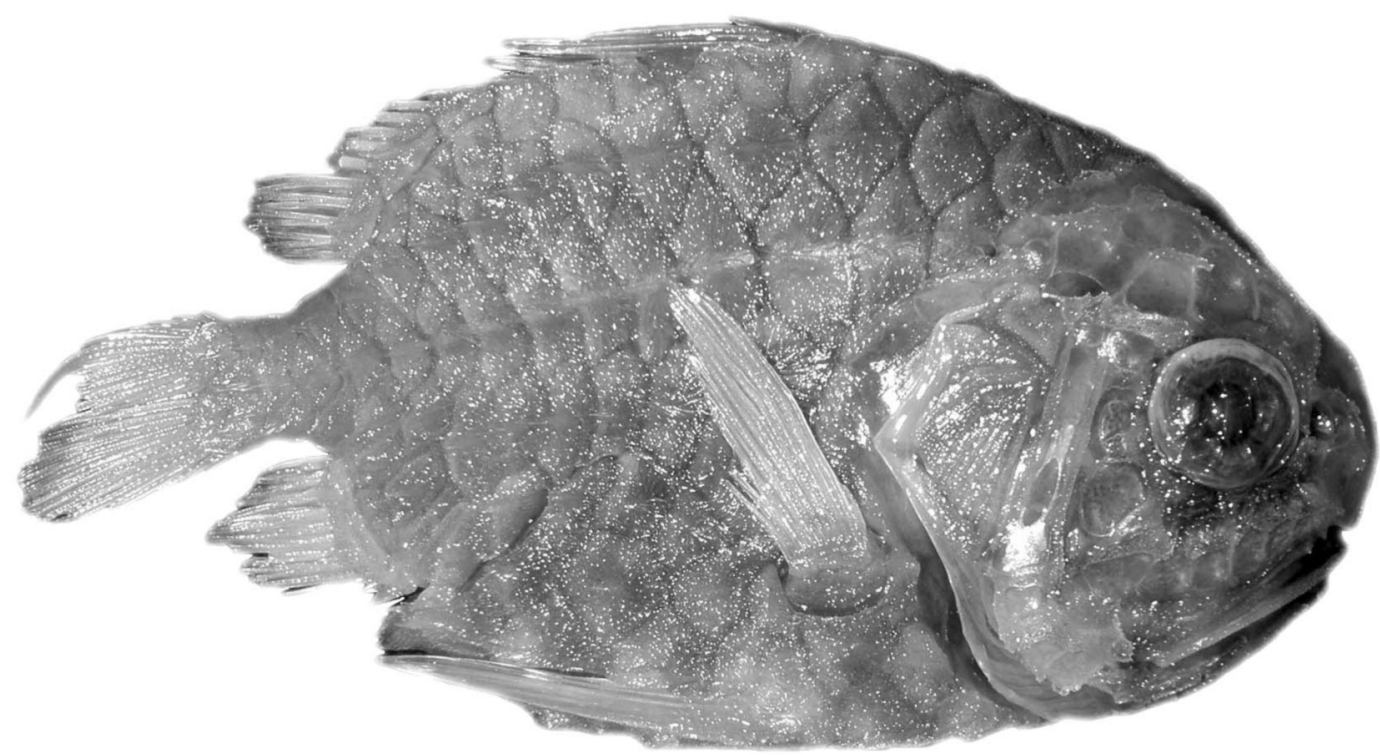

FIGURE 2. The pinecone fish (Monocentridae), named for its appearance, not its habitat. From the collections that were curated by Joe Nelson at the University of Alberta Museum of Zoology (UAMZ 7854).

assistants were classic 1960s incarnations of hairy, hard-working, hard-drinking biology students (both of whom went on to become famous Canadian fisheries personalities in their own right-another story...). At the end of each field day, a trip was made to the nearest small-town hotel for cold beer. The field assistants would drink multiple pints each, while Joe only ever ordered a single half-glass. The students teased him about his abstemious behaviour, calling him 'a Tiger!'

Joe was soft-spoken, but he had a rich and powerful voice. If he ever lost his temper, or swore, we are not aware of it. His strongest expletive was "Garsh!" For many of his biologist colleagues, however, the fact that Joe was also an accomplished martial artist, with a 7th degree black belt in Wado Karate, gave the impression that there was a hidden, perhaps less gentle, side to his personality. In fact, this was never the case. Joe took up the study of karate after a nerve-wracking mugging on a train platform in a foreign city he was visiting to attend a scientific conference, but he continued with it long after it was clear he could defend himself if need be, and he became a sensei (teacher) of others. As his fellow karateka Ken Wasserman put it at the memorial service, "Mighty as he was, this sensei always offered kindness and support, and patient leadership with constant emphasis on being a good citizen, perfection of one's own character, and respect for others and one's self." Joe was mighty, and he was compassionate. If anything, his legacy as a karate sensei and his legacy as an academic mentor are perfect mirror images of one another.
Joe was not a confrontational person by nature, but he did stand on points of principle. When a taxonomic name change occurred that shifted a number of trouts from the genus Salmo into the salmon genus $\mathrm{On}$ corhynchus, Joe was asked by those with a business interest if they could now market their salmon as the more valuable trout. Joe replied as a good taxonomist would: no, but if they wished to, they could now market their trout as salmon! When other taxonomists around him were caught up in the systematics wars of the 1980s, pitting cladists against pheneticists and evolutionary taxonomists, Joe practised a sort of academic judo, deflecting the attacks rather than battling them head-on. Although he leaned toward what was called "evolutionary taxonomy" himself, he understood and taught his students about the differences among the practices.

This non-confrontational manner, coupled with an ability to keep his mind on the truly important things, allowed Joe to sooth turbulent waters when necessary. A great example of this was during an important meeting regarding stream fragmentation caused by culverts acting as fish barriers. Representatives from federal and provincial fisheries agencies were arguing over issues such as Fisheries Act definitions of "important fish" and "critical habitat" and potential repercussions to industry. In the midst of a particularly heated discussion, Joe quietly but firmly interrupted and declared, "Anyone who prevents sticklebacks from spawning should be made to suffer the same fate." Everyone laughed, and the tone of the discussion reverted to a responsible discussion to solve a real problem. 
That story illustrates a key quality of Joe's personality. Joe Nelson was a gentleman, in the most honoured and delightful sense of the word. Always polite, always truthful and honest, always focused on the principles and importance of the bigger picture. MGS, who is periodically called upon as an expert witness, was deeply moved by Joe's example, and he keeps a small museum vial with a Brook Stickleback in the breast pocket of his going-to-court suit. During nasty crossexamination on questions of habitat destruction, he always feels for the stickleback and remembers that Joe taught him to be a gentleman." Joe taught many of us by example, although we may not all carry vials of fish in our pockets.

Joe could be serious, but he was also a playful man in many respects (he was actually caught on film flying down the hallway towards his office on a child's scooter). He retained an almost childlike fascination with and love of natural history throughout his life. He loved a good joke, and he especially loved a joke he could keep alive for a long time. Many of us remember the protracted kidding that Joe shared with his entomologist friends over the pinecone fish (Monocentridae). He innocently mentioned this fish (Figure 2) one day, but the entomologists said he was making it up, and a wonderful mythology developed in which the fish lived at the tops of pine trees, far from water.

He was a regular author of published letters to the editor in the Edmonton Journal, undoubtedly because his arguments were brief, clear, and diplomatic. When pet stores in Edmonton began carrying tropical fish with injected dyes to make them more colourful, Joe responded in typical fashion. His short and eloquent letter described the beauty of natural fishes, their immense diversity, and the wonder of their adaptations. The argument didn't criticize or offend anyone, yet it completely refuted the concept behind injecting colours into fish. As he would often instruct, "If you give politeness and respect, you get politeness and respect back. If you give anger and distrust, you get anger and distrust back." We think of those instructions, and his quiet adherence to them, as his most profound gift to those who knew him.

\section{Acknowledgements}

Some of the information in this article comes from an historical perspective by D. G. Smith (Copeia 2011 (1): 169-176) and the obituary in the Edmonton Journal (12 August 2011) and the Life \& Times article by Lana Cuthbertson, "Joseph Nelson Taught the World about Fish," 15 August 2011, page A4). We are grateful to Francis Cook for suggesting we undertake this tribute, The Canadian Field-Naturalist for providing us with a forum in which to express how much Joe Nelson meant to all of us, and to Brian Coad, Casimer
Lindsey, and Claude Renaud for reading and making suggestions on an earlier draft.

\section{Taxa described by J. S. Nelson}

Neophrynichthys angustus Nelson, 1977

Neophrynichthys magnicirrus Nelson, 1977

Limnichthys polyactis Nelson, 1978

Bembrops morelandi Nelson, 1978

Hemerocoetes morelandi Nelson, 1979

Hemerocoetes artus Nelson, 1979

Psychrolutes sio Nelson, 1980

Ebinania macquariensis Nelson, 1982

Ebinania malacocephala Nelson, 1982

Pteropsaron heemstrai Nelson, 1982

Osopsaron natalensis Nelson, 1982

Creedia alleni Nelson, 1983

Creedia partimsquamigera Nelson, 1983

Crystallodytes pauciradiatus Nelson and Randall, 1985

Cottunculus nudus Nelson, 1989

Psychrolutes microporos Nelson, 1995

Bembrops cadenati Das and Nelson, 1996

Ambophthalmus Jackson and Nelson, 1998

Ambophthalmus eurystigmatephoros Jackson and Nelson, 1999

Neophrynichthys heterospilos Jackson and Nelson, 2000

Ebinania australiae Jackson and Nelson, 2006

\section{Bibliography of J. S. Nelson}

\section{Theses}

B.Sc. 1960. Variation in meristic characters of kokanee populations (Oncorhynchus nerka) in British Columbia with an appendix on their distribution throughout North America. B.Sc. thesis, Department of Zoology, University of British Columbia, Vancouver, British Columbia. 64 pages.

M.Sc. 1962. Effects on fishes of changes within the Kananaskis River system. M.Sc. thesis, Department of Zoology, University of Alberta, Edmonton, Alberta. 107 pages.

Ph.D. 1965. Hybridization and isolating mechanisms in Catostomus commersonii and Catostomus macrocheilus (Pisces: Catostomidae). Ph.D. thesis, University of British Columbia, Vancouver, British Columbia. 100 pages.

Refereed publications

Gordon, R. N., R. A. Crouter, and J. S. Nelson. 1960. The fish facilities at the Whitehorse Rapids power development, Yukon Territory. Canadian Fish Culturalist 27: 1-14.

Hickman, C. P., R. A. McNabb, J. S. Nelson, E. D. Van Breeman, and D. Comfort. 1964. Effect of cold acclimation on electrolyte distribution in rainbow trout (Salmo gairdnerii). Canadian Journal of Zoology 42: 577-597.

Nelson, J. S. 1965. Effects of fish introductions and hydroelectric development on the fishes of the Kananaskis River system, Alberta. Journal of the Fisheries Research Board of Canada 22(3): 721-753.

Nelson, J. S. 1966. Hybridization between two cyprinid fishes, Hybopsis plumbea and Rhinichthys cataractae, in Alberta. Canadian Journal of Zoology 44(5): 963-968.

Nelson, J. S. 1968. Hybridization and isolating mechanisms between Catostomus commersonii and C. macrocheilus (Pisces: Catostomidae). Journal of the Fisheries Research Board of Canada 25(1): 101-150. 
Nelson, J. S. 1968. Distribution and nomenclature of North American kokanee, Oncorhynchus nerka. Journal of the Fisheries Research Board of Canada 25(2): 409-414.

Nelson, J. S. 1968. Variation in gillraker number of North American kokanee, Oncorhynchus nerka. Journal of the Fisheries Research Board of Canada 25(2): 415-420.

Nelson, J. S. 1968. Deep-water ninespine sticklebacks, Pungitius pungitius, in the Mississippi drainage, Crooked Lake, Indiana. Copeia 1968(2): 326-334.

Nelson, J. S. 1968. Life history of the brook silverside, Labidesthes sicculus, in Crooked Lake, Indiana. Transactions of the American Fisheries Society 97(3): 293-296.

Nelson, J. S. 1968. Salinity tolerance of brook sticklebacks, Culaea inconstans, freshwater ninespine sticklebacks, Pungitius pungitius, and freshwater fourspine sticklebacks, Apeltes quadracus. Canadian Journal of Zoology 46(4): 663-667.

Nelson, J. S. 1968. Ecology of the southernmost sympatric population of the brook stickleback, Culaea inconstans, and the ninespine stickleback, Pungitius pungitius, in Crooked Lake, Indiana. Proceedings of the Indiana Academy of Science 77: 185-192.

Nelson, J. S. 1969. Geographic variation in the brook stickleback, Culaea inconstans, and notes on nomenclature and distribution. Journal of the Fisheries Research Board of Canada 26(9): 2431-2447.

Paetz, M. J., and J. S. Nelson. 1970. The Fishes of Alberta. Queen's Printer, Edmonton. 282 pages.

Nelson, J. S., and F. M. Atton. 1971. Geographic and morphological variation in the presence and absence of the pelvic skeleton in the brook stickleback, Culaea inconstans (Kirtland), in Alberta and Saskatchewan. Canadian Journal of Zoology 49(3): 343-352.

Nelson, J. S. 1971. Comparison of the pectoral and pelvic skeleton and of some other bones and their phylogenetic implications in the Aulorhynchidae and Gasterosteidae (Pisces). Journal of the Fisheries Research Board of Canada 28(3): 427-442.

Nelson, J. S. 1971. Absence of the pelvic complex in ninespine sticklebacks, Pungitius pungitius (Linnaeus), in Ireland and in Wood Buffalo National Park region, Canada, with notes on meristic variation. Copeia 1971(4): 707-717.

Nelson, J. S., and M. J. Paetz. 1972. Fishes of the northeastern Wood Buffalo National Park region, Alberta and Northwest Territories. Canadian Field-Naturalist 86(2): 133-144.

Nelson, J. S. 1973. Morphological difference between the teleosts Couesius plumbeus (lake chub) and Rhinichthys cataractae (longnose dace) and their hybrids from Alberta. Journal of Morphology 139(2): 227-237.

Nelson, J. S. 1973. Occurrence of hybrids between longnose sucker (Catostomus catostomus) and white sucker $(C$. commersoni) in Upper Kananaskis Reservoir, Alberta. Journal of the Fisheries Research Board of Canada 30(4): 557560.

Nelson, J. S., and M. J. Paetz. 1974. Evidence for underground movement of fishes in Wood Buffalo National Park, Canada, with notes on recent collections made in the park. Canadian Field-Naturalist 88(2): 157-162.

Nelson, J. S. 1974. Hybridization between Catostomus commersoni (white sucker) and Catostomus macrocheilus (largescale sucker) in Williston Reservoir, British Columbia, with notes on other fishes. Syesis 7: 187-194.
Nelson, J. S. 1975. Records of a new form of the marine cottid fish Antipodocottus galatheae from the east coast of New Zealand. Records of the National Museum of New Zealand 1(4): 80-86.

Nelson, J. S. 1976. Fishes of the World. Wiley-Interscience, New York. 416 pages.

Nelson, J. S. 1976. Sticklebacks in our ponds. Kinnikinick 1(7): 114-116.

Nelson, J. S. 1977. Evidence of a genetic basis for absence of the pelvic skeleton in brook sticklebacks, Culaea inconstans, and notes on the geographical distribution and origin of the loss. Journal of the Fisheries Research Board of Canada 34(9): 1314-1420.

Nelson, J. S. 1977. Fishes of the Southern Hemisphere genus Neophrynichthys (Scorpaeniformes: Cottoidei), with descriptions of two new species from New Zealand and Macquarie Island. Journal of the Royal Society of New Zealand 7(4): 485-511.

Nelson, J. S. 1977. The postglacial invasion of fishes into Alberta. Alberta Naturalist 7(2): 129-139.

Nelson, J. S. 1978. Limnichthys polyactis, a new species of blennioid fish from New Zealand, with notes on the taxonomy and distribution of other Creediidae (including Limnichthyidae). New Zealand Journal of Zoology 5(2): 351-364.

Nelson, J. S. 1978. Bembrops morelandi, a new percophidid fish from New Zealand, with notes on other members of the genus. Records of the National Museum of New Zealand 1: 237-241.

Nelson, J. S. 1979. Some osteological differences between the blennioid fishes Limnichthys polyactis and L. rendahli, with comments on other species of Creediidae. New Zealand Journal of Zoology 6: 273-277.

Nelson, J. S. 1979. Revision of the fishes of the New Zealand genus Hemerocoetes (Perciformes: Percophididae), with descriptions of two new species. New Zealand Journal of Zoology 6: 587-599.

Nelson, J. S. 1979. Relative numbers of vertebrate species in Alberta, Canada, and the world. Alberta Naturalist 9(3): 145-152.

Nelson, J. S. 1980. Psychrolutes sio, a new psychrolutid fish (Scorpaeniformes) from the southeastern Pacific. Canadian Journal of Zoology 58: 443-449.

Nelson, J. S., and I. Nakamura. 1980. Distribution, morphology, and taxonomy of the psychrolutid fish Cottunculus granulosus (Karrer) from the southwestern Atlantic. Canadian Journal of Zoology 58: 982-990.

Nelson, J. S., and M. J. Paetz. 1982. Endangered species/ habitats-Alberta fish species. Alberta Naturalist 12(2): 52-53.

Nelson, J. S. 1982. Two new South Pacific fishes of the genus Ebinania and contributions to the sytematics of Psychrolutidae (Scorpaeniformes). Canadian Journal of Zoology 60: 1470-1504.

Nelson, J. S. 1982. Pteropsaron heemstrai and Osopsaron natalensis (Perciformes: Percophidae), new fish species from South Africa, with comments on Squamicreedia obtusa from Australia and on the classification of the subfamily Hemerocoetinae. Special Publication (25), J.L.B. Smith Institute of Ichthyology. 11 pages.

Nelson, J. S. 1983. Creedia alleni and Creedia partimsquamigera (Perciformes: Creediidae), two new marine fish species from Australia, with notes on other Australian creediids. Proceedings of the Biological Society of Washington 96(1): 29-37. 
Nelson, J. S. 1983. The tropical fish fauna in Cave and Basin Hotsprings drainage, Banff National Park. Canadian Field-Naturalist 97(3): 255-261.

Heemstra, P. C., and J. S. Nelson. 1984. Percophidae. FAO species identification sheets. Fishing area 51. Volume III. Food and Agriculture Organization of the United Nations, Rome. 2 pages.

Nelson, J. S. 1984. Fishes of the World. Second edition. John Wiley and Sons, New York. 523 pages.

Nelson, J. S. 1985. On the relationship of the New Zealand marine fish Antipodocottus galatheae with the Japanese Stlengis misakia (Scorpaeniformes: Cottidae). New Zealand Oceanographic Institute Record 5(1): 1-12.

Nelson, J. S. 1985. Fish. Pages 638-639 in The Canadian Encyclopedia. Hurtig Publishers, Edmonton.

Nelson, J. S. 1985. Fish classification. Page 639 in The Canadian Encyclopedia. Hurtig Publishers, Edmonton.

Nelson, J. S. 1985. Stickleback. Pages 1760-1761 in The Canadian Encyclopedia. Hurtig Publishers, Edmonton.

Nelson, J. S. 1985. Sucker. Page 1768 in The Canadian Encyclopedia. Hurtig Publishers, Edmonton.

Nelson, J. S. 1985. On the interrelationships of the genera of Creediidae (Perciformes: Trachinoidei). Japanese Journal of Ichthyology 32(3): 283-293.

Nelson, J. S., N. Chirichigno, and F. Balbontin. 1985. New material of Psychrolutes sio (Scorpaeniformes, Psychrolutidae) from the eastern Pacific of South America, and comments on the taxonomy of Psychrolutes inermis and Psychrolutes macrocephalus from the eastern Atlantic of Africa. Canadian Journal of Zoolology 63: 444-451.

Nelson, J. S., and J. E. Randall. 1985. Crystallodytes pauciradiatus (Perciformes), a new creediid fish species from Easter Island. Proceedings of the Biological Society of Washington 98(2): 403-410.

Reimchen, T. E., E. M. Stinson, and J. S. Nelson. 1985. Multivariate differentiation of parapatric and allopatric populations of threespine stickleback in the Sangan River watershed, Queen Charlotte Islands. Canadian Journal of Zoology 63: 2944-2951.

Fedorov, V. V., and J. S. Nelson. 1986. Psychrolutidae. Pages 1261-1264 in Volume III of Fishes of the North-eastern Atlantic and the Mediterranean. Edited by P. J. P. Whitehead, M-L. Bauchot, J-C. Hureau, J. Nielsen, and E. Tortonese. UNESCO, Paris.

Heemstra, P. C., and J. S. Nelson. 1986. Family No. 233: Percophidae. Pages 737-739 in Smiths' Sea Fishes. Edited by M. M. Smith and P. C. Heemstra. J. L. B. Smith Institute of Ichthyology, Grahamstown, South Africa, and Macmillan South Africa, Johannesburg.

Nelson, J. S. 1986. Family No. 232: Creediidae. Pages 736737 in Smiths' Sea Fishes. Edited by M. M. Smith and P. C. Heemstra. J.L.B. Smith Institute of Ichthyology, Grahamstown, South Africa, and Macmillan South Africa, Johannesburg.

Nelson, J. S. 1986. Family No. 160: Psychrolutidae. Pages 491-492 in Smith's Sea Fishes. Edited by M. M. Smith and P. C. Heemstra. J.L.B. Smith Institute of Ichthyology, Grahamstown, South Africa, and Macmillan South Africa, Johannesburg.

Nelson, J. S. 1986. Some characters of Trichonotidae, with emphasis to those distinguishing it from Creediidae (Perciformes: Trachinoidei). Japanese Journal of Ichthyology 33(1): 1-6.

Nelson, J. S. 1987. The next twenty-five years: vertebrate systematics. Canadian Journal of Zoology 65(4): 779-785.
Nelson, J. S., and M. A. Harris. 1987. Morphological characteristics of an introduced threespine stickleback, Gasterosteus aculeatus, from Hasse Lake, Alberta: a first occurrence in the interior plains of North America. Environmental Biology of Fishes 18(3): 173-181.

Reimchen, T. E., and J. S. Nelson. 1987. Habitat and morphological correlates to vertebral number as shown in a teleost, Gasterosteus aculeatus. Copeia 1987(4): 868-874.

Das, M. K., and J. S. Nelson. 1988. Hybridization between northern redbelly dace (Phoxinus eos) and finescale dace (Phoxinus neogaeus) (Osteichthyes: Cyprinidae) in Alberta. Canadian Journal of Zoology 67: 579-584.

Nelson, J. S. 1989. Cottunculus nudus, a new psychrolutid fish from New Zealand (Scorpaeniformes: Cottoidei). Copeia 1989(2): 401-408.

Nelson, J. S. 1990. Atlantic fishes of Canada: a review. Bulletin of the Canadian Society of Zoologists 21(3): 36-37.

Nelson, J. S. 1990. Redescription of Antipodocottus elegans (Scorpaeniformes: Cottidae) from Australia, with comments on the genus. Copeia 1990(3): 840-846.

Nelson, J. S. 1990. Indo-Pacific fish conference. Copeia. 1990(3): 906-907.

Nelson, J. S. 1990. Psychrolutidae. Pages 687-688 in CLOFETA. Volume II of Check-list of the Fishes of the Eastern Tropical Atlantic. Edited by J. C. Quéro, J. C. Hureau, C. Karrer, A. Post, and L. Saldanha. UNESCO, Paris.

Das, M. K., and J. S. Nelson. 1990. Spawning time and fecundity of northern redbelly dace, Phoxinus eos, finescale dace, Phoxinus neogaeus, and their hybrids in Upper Pierre Grey Lake, Alberta. Canadian Field-Naturalist 104(3): 409-413.

Winfield, I. J., and J. S. Nelson (Editors). 1991. Cyprinid Fishes: Systematics, Biology and Exploitation. Chapman and Hall Ltd., London. 667 pages.

Nelson, J. S. 1991. Comments on the need for stability in fish family-group names. Bulletin of Zoological Nomenclature 48(2): 147-148.

Nelson, J. S. 1991. Comments on Balitoridae. Bulletin of Zoological Nomenclature 48(4): 335.

Nelson, J. S. 1991. Foreword. Pages vii-viii in Fish Evolution and Taxonomy: Evidence from Spermatozoa. Edited by B. G. M. Jamieson. Cambridge University Press.

Nelson, J. S., and M. J. Paetz. 1992. The Fishes of Alberta. University of Alberta Press, Edmonton, and University of Calgary Press, Calgary. 437 pages.

Nelson, J. S. [1993] 1989/1990. Analysis of the multiple occurrence of pelvic fin absence in extant fishes. Matsya, Bulletin of the Indian Society of Ichthyologists 15/16: 2138.

Nelson, J. S. 1994. Fishes of the World. Third edition. John Wiley and Sons, Inc., New York. 600 pages.

Nelson, J. S. 1994. Fishes of the world [Chinese translation of second edition]. Sueichan Press, Taiwan. 614 pages.

Nelson, J. S. 1994. Foreword in Lake, River, and Sea-run fishes of Canada. Edited by F. H. Wooding. Harbour Publishing, Madeira Park, British Columbia.

Brewin, M. K., L. L. Stebbins, and J. S. Nelson. 1995. Differential losses of floy anchor tags between male and female brown trout. North American Journal of Fisheries Management 15: 881-884.

Nelson, J. S. 1995. Psychrolutes microporos, a new species of cottoid (Teleostei: Scorpaeniformes) from New Zealand and Japan with biogeographical comments. Proceedings of the Zoolological Society, Calcutta 48(2): 67-76. 
Das, M. K., and J. S. Nelson. 1996. Revision of the percophid genus Bembrops (Actinopterygii: Perciformes). Bulletin of Marine Science 59(1): 9-44.

Keivany, Y., J. S. Nelson, and P. S. Economidis. 1997. Validity of Pungitius hellenicus Stephanidis 1971 (Teleostei, Gasterosteidae), a stickleback fish from Greece. Copeia 1997(3): 558-564.

Keivany, Y., and J. S. Nelson. 1998. Comparative osteology of the Greek ninespine stickleback, Pungitius pungitius (Teleostei, Gasterosteidae). Voprosy Ikhtiologii 38(4): 458468, and Journal of Ichthyology (English translation) 38(6): 430-440.

Nelson, J. S., and B. Shelast. 1998. Pygmy whitefish in the Athabasca River near Whitecourt, Alberta. Alberta Naturalist 28(3): 59-60.

Jackson, K. L., and J. S. Nelson. 1998. Ambophthalmos, a new genus for "Neophrynichthys" angustus and "Neophrynichthys" magnicirrus, and the systematic interrelationships of the fathead sculpins (Cottoidei, Psychrolutidae). Canadian Journal of Zoology 76(7): 1344-1357.

Nelson, J. S., E. J. Crossman, H. Espinosa-Pérez, C. R. Gilbert, R. N. Lea, and J. D. Williams. 1998. Recommended changes in common fish names: pikeminnow to replace squawfish (Ptychocheilus spp.). Fisheries 23(9): 37.

Jackson, K. L., and J. S. Nelson. 1999. Ambophthalmos eurystigmatephoros, a new species of fathead sculpin (Scorpaeniformes: Psychrolutidae) from New Zealand. Copeia 1999(2): 428-433.

Keivany, Y., C. K. Daoulas, J. S. Nelson, and P. S. Economidis. 1999. Threatened fishes of the world: Pungitius hellenicus Stephanidis, 1971 (Gasterosteidae). Environmental Biology of Fishes 55: 390.

Nelson, J. S. 1999. Editorial and introduction: the species concept in fish biology. Reviews in Fish Biology and Fisheries 9(4): 277-280.

Nelson, J. S., and P. J. B. Hart. (Editors). 1999. The species concept in fish biology. Reviews in Fish Biology and Fisheries 9(4): 277-382.

Nelson, J. S., and K. E. Carpenter. 1999. Cottidae, sculpins. Pages 2425-2426 in Volume 4, part 2 of The Living Marine Resources of the Western Central Pacific. Edited by K. E. Carpenter and V. H. Niem. FAO Species Identification Guide for Fishery Purposes. Food and Agriculture Organization of the United Nations, Rome.

Nelson, J. S. 1999. Psychrolutidae, fathead sculpins. Pages 2427-2428 in Volume. 4, part 2 of The Living Marine Resources of the Western Central Pacific. Edited by K. E. Carpenter and V. H. Niem. FAO Species Identification Guide for Fishery Purposes. Food and Agriculture Organization of the United Nations, Rome.

Nelson, J. S. 2000. Trichonotidae, and Creediidae. Page 631 in A Checklist of the Fishes of the South China Sea. Edited by J. E. Randall and K. K. P. Lim. Raffles Bulletin of Zoology, Supplement 8.

Keivany, Y., and J. S. Nelson. 2000. Taxonomic review of the genus Pungitius, ninespine sticklebacks (Gasterosteidae). Cybium 24(2):107-122.

Jackson, K. L,. and J. S. Nelson. 2000. Neophrynichthys heterospilos, a new species of fathead sculpin (Scorpaeniformes: Psychrolutidae) from New Zealand. New Zealand Journal of Marine and Freshwater Research 34(4): 719726.

Gilbert, C. R., J. S. Nelson, E. J. Crossman, H. EspinosaPérez, L. T. Findley, R. N. Lea, and J. D. Williams.
2000. Ceratichthys micropogon Cope, 1865 (currently Nocomis micropogon; Osteichthyes, Cypriniformes): proposed conservation of usage of the specific name by the designation of a neotype. Bulletin of Zoological Nomenclature 57(4):214-217.

Gilbert, C. R., J. S. Nelson, E. J. Crossman, H. Espinosa-Pérez, L. T. Findley, R. N. Lea, and J. D. Williams. 2000. Holacanthus ciliaris bermudensis Goode, 1876 (currently Holacanthus bermudensis; Osteichthyes, Perciformes): proposed conservation of usage of the subspecific name by the designation of a neotype. Bulletin of Zoological Nomenclature 57(4): 218-222.

Nelson, J. S., E. J. Crossman, H. Espinosa-Pérez, L. T. Findley, C. R. Gilbert, R. N. Lea, and J. D. Williams. 2001. Recommended change in the common name for a marine fish: goliath grouper to replace jewfish (Epinephelus itajara). Fisheries 26(5): 31.

Nelson, J. S. 2001. Trichonotidae, Sanddivers. Pages 35113512 in Volume 6, part 4 of The Living marine Resources of the Western Central Pacific. Edited by K. E. Carpenter and V. H. Niem FAO Species Identification Guide for Fishery Purposes, Food and Agriculture Organization of the United Nations, Rome.

Nelson, J. S. 2001. Creediidae, Sandburrowers. Pages 35133514 in Volume. 6, part 4 of The Living Marine Resources of the Western Central Pacific. Edited by K. E. Carpenter and V. H. Niem. FAO Species Identification Guide for Fishery Purposes. Food and Agriculture Organization of the United Nations, Rome.

Nelson, J. S. 2001. Percophidae, Duckbills. Pages 3515-3516 in Volume 6, part 4 of The Living Marine Resources of the Western Central Pacific. Edited by K. E. Carpenter and V. H. Name. FAO Species Identification Guide for Fishery Purposes. Food and Agriculture Organization of the United Nations, Rome.

Nelson, J. S., E. J. Crossman, H. Espinosa-Pérez, L. T. Findley, C. R. Gilbert, R. N. Lea, and J. D. Williams. 2002. When is a catfish not a catfish-U. S. legislation over a name. Fisheries 27(2): 38-40.

Nelson, J. S., W. C. Starnes, and M. L. Warren. 2002. A capital case for common names of species of fishes-a white crappie or a White Crappie. Fisheries 27(7): 31-33.

Steinhilber, M., J. S. Nelson, and J. D. Reist. 2002. A morphological and genetic re-examination of sympatric shortjaw cisco (Coregonus zenithicus) and lake cisco (C. artedi) in Barrow Lake, Alberta, Canada. Proceedings of the VII International Symposium on the Biology and Management of Coregonid Fishes, Ann Arbor, Michigan, 1999. Edited by Todd Thomas and Guy Fleisher. Advances in Limnology / Special issue of Archives of Hydrobiology (Archive für Hydrobiologie) 57: 463-478.

Nelson, J. S., E. J. Crossman, H. Espinosa-Pérez, L. T. Findley, C. R. Gilbert, R. N. Lea, and J. D. Williams. 2003. The "Names of Fishes" list, including recommended changes in fish names: Chinook salmon for chinook salmon, and Sander to replace Stizostedion for the sauger and walleye. Fisheries 28(7):38-39.

Nelson, J. S. 2003. Foreword. In Fish of Alberta. Edited by A. Joynt and M. G. Sullivan. Lone Pine Publishing, Edmonton. 176 pages.

Nelson, J. S. 2004. Foreword. In Darwin's Fishes, an Encyclopedia of Ichthyology, Ecology and Evolution. By D. Pauly. Cambridge University Press, Cambridge, United Kingdom. 340 pages. 
Nelson, J. S., E. J. Crossman, H. Espinosa-Pérez, L. T. Findley, C. R. Gilbert, R. N. Lea, and J. D. Williams. 2004. Common and scientific names of fishes from the United States, Canada, and Mexico. Sixth edition. Special Publication 29. American Fisheries Society, Bethesda, Maryland. 386 pages with CD.

Keivany, Y., and J. S. Nelson. 2004. Phylogenetic relationships of sticklebacks (Gasterosteidae), with emphasis on ninespine sticklebacks (Pungitius spp.). Behaviour 141 (11/12): 1485-1497.

Nelson, J. S. 2006. Fishes of the World. Fourth edition. John Wiley and Sons, Inc., New York. 601 pages.

Nelson, J. S., H. Espinosa-Pérez, L. T. Findley, C. R. Gilbert, R. N. Lea, N. E. Mandrak, and J. D. Williams. 2006. Corrections to common and scientific names of fishes from the United States, Canada, and Mexico. Sixth edition. Fisheries 31(3): 138-140.

Jackson, K. L., and J. S. Nelson. 2006. Ebinania australi$a e$, a new species of fathead sculpin from southern Australia (Scorpaeniformes: Psychrolutidae). Records of the Australian Museum 58: 37-42.

Nelson, J. S., H. Espinosa-Pérez, L. T. Findley, C. R. Gilbert, R. N. Lea, N. E. Mandrak, and J. D. Williams. 2006. Corrections to "Common and Scientific Names of Fishes from the United States, Canada, and Mexico." Copeia 2006(3): 559-562.

Nelson, J. S., H. Espinosa-Pérez, L. T. Findley, C. R. Gilbert, R. N. Lea, N. E. Mandrak, and J. D. Williams. 2006. Comment on the proposed reinstatement of the specific name of Sphyraena acus Lacepède, 1803 (currently Tylosurus acus; Teleostei, Belonidae). Bulletin of Zoological Nomenclature 63(1): 48-49.

Nelson, J. S. 2006. Fish. In The Canadian Encyclopedia. Revised. 4 pages. http://thecanadianencyclopedia.com.

Nelson, J. S. 2006. Fish classification. In The Canadian Encyclopedia. Revised. 7 pages. http://thecanadianency clopedia.com.

Nelson, J. S. 2006. Stickleback. In The Canadian Encyclopedia. Revised. 1 page. http://thecanadianencyclopedia .com.

Nelson, J. S. 2006. Sucker. In The Canadian Encyclopedia. Revised. 1 page. http://thecanadianencyclopedia.com.

Keivany, Y. , and J. S. Nelson. 2006. Interrelationships of Gasterosteiformes (Actinopterygii, Percomorpha). Journal of Ichthyology 46, supplement 1: S84-S96.

Nelson, J. S. 2007. Foreword. In The Freshwater Fishes of British Columbia. Edited by J. D. McPhail. University of Alberta Press. 620 pages.

Jelks, H. L., S. J. Walsh, N. M. Burkhead, S. ContrerasBalderas, E. Díaz-Pardo, D. A. Hendrickson, J. Lyons, N. E. Mandrak, F. McCormick, J. S. Nelson, S. P. Platania, B. A. Porter, C. B. Renaud, J. J. SchmitterSoto, E. B. Taylor, and M. L. Warren, Jr. 2008. Conservation status of imperiled North American freshwater and diadromous fishes. Fisheries 33(8): 372-407.
Nelson, J. S., H.-P. Schultze, and M. V. H. Wilson (Editors). 2010. Origin and Phylogenetic Interrelationships of Teleosts: Honoring Gloria Arratia. 20 chapters. Verlag Dr. Friedrich Pfeil, München.

Nelson, J. S. 2010. Gloria Arratia's contribution to our understanding of lower teleostean phylogeny and classification. Pages 11-36 in Origin and Phylogenetic Interrelationships of Teleosts: Honoring Gloria Arratia. Edited by J. S. Nelson, H.-P. Schultze, and M. V. H. Wilson. 20 chapters. Verlag Dr. Friedrich Pfeil, München.

Lea, R. N., H. Espinosa-Pérez, L. T. Findley, C. R. Gilbert, N. E. Mandrak, R. L. Mayden, J. S. Nelson, and L. M. Page. 2010. Comments on Raja say Le Sueur, 1817 (currently Dasyatis say; Chondrichthyes, Myliobatiformes, Dasyatidae): proposed change of spelling to Raja sayi Le Sueur, 1817 (Case 3410; see BZN 65: 119-123). Bulletin of Zoological Nomenclature 67(1): 66-67.

Nelson, J. S. (submitted). Reduction in variation of pelvic skeleton phenotypes in breeding experiments and temporal stability of pelvic phenotypes of brook stickleback, Culaea inconstans (Gasterosteidae), from Astotin Lake, Alberta. Canadian Journal of Zoology.

Miscellaneous publications

Nelson, J. S. 1972. Review of H. B. N. Hynes, The ecology of running waters. Canadian Field-Naturalist 86(1): 108-109.

Nelson, J. S. 1978. Review of R. J. Wootton, The biology of the sticklebacks. Copeia 1978(3): 552-554.

Nelson, J. S. 1980. Review of C. E. Bond, Biology of fishes. Canadian Field-Naturalist 94(1): 99.

Nelson, J. S. 1991. The systematics of Cottunculus and Neophrynichthys (Psychrolutidae). Abstracts of presentations: Seventh International Ichthyology Congress, The Hague, Netherlands, 26-30 August 1991. Bulletin Zoölogisch Museum, Universiteit van Amsterdam, Special Issue 1991: 55.

Nelson, J. S. 1991. Review of The Eurasian Huchen, Hucho hucho, largest salmon of the world. Copeia 1991(2): 537538.

Nelson, J. S. 1991. Review of Catalog of the genera of recent fishes. Copeia 1991(4): 1156-1158.

Nelson, J. S. 1992. Review of A field guide to freshwater fishes: North America North of Mexico. Reviews in Fish Biology and Fisheries 2(3): 279-280.

Nelson, J. S. 1994. Review of $A$ history and atlas of the fishes of the Antarctic Ocean. Global Biodiversity 3: 40-41.

Nelson, J. S. 1995. Review of Biology of fishes. Reviews in Fish Biology and Fisheries 5(4): 464-465.

Nelson, J. S. 1997. Review of Interrelationships of fishes. Copeia 1997(3): 647-649.

Nelson, J. S. 1997. Review of Encyclopedia of Canadian fishes. Canadian Book Review Annual (CBRA): 1008.

Nelson, J. S. 2008. Review of Heiko Bleher, Bleher's Discus, Volume 1. Aqua: International Journal of Ichthyology 14(2): 101-103.

Received 15 February 2012

Accepted 16 April 2012 